\title{
Konflik versus Kooperasi: Upaya Penyelesaian Sengketa Laut Tiongkok Selatan dan Integrasi ASEAN ke Iklim Ekonomi Global*
}

\author{
Garry Gumelar Pratama**
}

\begin{abstract}
Abstrak
Negara-negara ASEAN tengah mencanangkan untuk melaksanakan integrasi ekonomi, tak hanya intra-regional namun juga integrasi regional terhadap iklim ekonomi global. Namun demikian, negara-negara ASEAN sampai saat ini masih menghadapi sengketa internasional mengenai Laut Tiongkok Selatan. Sengketa antara negara-negara ASEAN dan Tiongkok tersebut dianggap sebagai sengketa yang paling rumit pada abad ke-21. Terlebih lagi, Tiongkok cenderung untuk menghindari hukum internasional dalam isu tersebut. Tulisan ini akan menganalisis bagaimana Sengketa Laut Tiongkok Selatan yang sulit diselesaikan dengan hukum internasional dapat menghambat integrasi ASEAN ke iklim ekonomi global. Dalam hal ini, peran serta ASEAN dalam menyelesaikan masalah sengketa internasional harus diberikan porsi yang sama besarnya dengan upaya integrasi ekonomi. Untuk itu, artikel ini juga akan berusaha mencari model penyelesaian sengketa internasional yang dapat dilakukan ASEAN untuk meredam konflik dan mendorong kesuksesan integrasi ekonomi ASEAN ke Iklim ekonomi global.
\end{abstract}

Kata Kunci: konflik, kooperasi, penyelesaian sengketa, Laut Tiongkok Selatan, integrasi ASEAN.

\section{Conflict v. Cooperation: The South China Sea Dispute Settlement and ASEAN Integration to Global Economic}

\begin{abstract}
ASEAN is planning to implement an economic integration, not only intra-regional economic integration but also integration to the global economic. Nevertheless, ASEAN countries up until now are still facing international disputes concerning the South China Sea. The dispute between ASEAN countries and China is regarded as the most complex dispute in the 21st Century. Moreover, China tends to avoid international law in the issue. This paper will analyze how the complicated South China Sea international dispute may impede ASEAN integration to the global economic. In this regard, the role of ASEAN in resolving the international dispute should be given the same portion as economic integration efforts. To that end, this article will also seek international dispute resolution model that can be used by ASEAN to reduce conflict and enhance the success of ASEAN's economic integration to the globaleconomic.
\end{abstract}

Keywords: conflict, cooperation, settlement of disputes, the South China Sea, ASEAN integration.

PADJADJARAN Jurnal IImu Hukum Volume 3 Nomor 1 Tahun 2016 [ISSN 2460-1543] [e-ISSN 2442-9325]

* Dosen Hukum Internasional Fakultas Hukum Universitas Padjadjaran, Jl. Dipati Ukur No. 35 Bandung, garry.gumelar@unpad.ac.id, S.H., M.H. (Universitas Padjadjaran) 


\section{A. Pendahuluan}

Association of South East Asian Nations (ASEAN) merupakan organisasi internasional regional yang terdiri dari sepuluh negara di Asia Tenggara, yaitu: Brunei Darussalam, Kamboja, Indonesia, Laos, Malaysia, Myanmar, Filipina, Singapura, Thailand, dan Vietnam. ${ }^{1}$ Dengan keberagaman latar belakang negara anggota ASEAN, Asia Tenggara menjadi regional yang memiliki sejarah, budaya, politik, dan ekonomi yang sangat beragam. ${ }^{2}$ Di tengah keberagaman tersebut, ternyata negara-negara di Asia Tenggara memiliki potensi ekonomi yang besar, maka apabila kekuatan ekonomi seluruh negara anggota ASEAN digabungkan menjadi satu negara, ASEAN setara dengan negara peringkat ke-7 dunia berkekuatan ekonomi terbesar. ${ }^{3}$

Dengan potensi demikian, sepuluh negara Asia Tenggara telah mencanangkan untuk saling berintegrasi melalui ASEAN Community yang terdiri dari tiga pilar, yaitu: ASEAN Economic Community (Komunitas Ekonomi ASEAN), ASEAN PoliticalSecurity Community (Komunitas Politik-Keamanan ASEAN), dan ASEAN SocialCultural Community (Komunitas Sosio-Kultural ASEAN). ${ }^{4}$ Keseluruhan komunitas tersebut merupakan upaya mewujudkan Visi ASEAN pada 2020 untuk menjadi regional yang stabil, makmur, dan berdaya saing tinggi. ${ }^{5}$

Usaha untuk merealisasikan Komunitas Ekonomi ASEAN oleh negara-negara ASEAN sebenarnya sudah muncul sejak tahun 2003 saat diselenggarakannya ASEAN Summit di Bali. ${ }^{6}$ Sejak saat itu, liberalisasi perdagangan terus menggema di ASEAN. Selain itu, untuk mempercepat pencapaian Visi ASEAN 2020, negara-negara ASEAN pun berkomitmen untuk mencapai pembentukan Komunitas Ekonomi ASEAN pada 2015.7

Komunitas Ekonomi ASEAN sebagai bentuk integrasi ekonomi diharapkan akan meningkatkan ekspor barang maupun jasa lebih mudah. Para produsen dari suatu negara di ASEAN dapat mengekspor produknya ke negara ASEAN lainnya dengan

1 Pasal 4 Charter of The Association of Southeast Asian Nation 2007 (ASEAN Charter 2007), lihat juga ASEAN, "ASEAN Member States", http://asean.org/asean/asean-member-states/, diakses 13 Juni 2016 Pukul 14.00 WIB.

2 Vannarith Chheang, "Tourism and Regional Integration in Southeast Asia", http://www.ide.go.jp/English/Publish/Download/Vrf/pdf/481.pdf, hlm. 1.

3 HIS, International Monetary Fund, World Ecnomic Outlook dalam McKinsey\& Company, "Understanding Asean: Seven Things You Need to Know", http://www.mckinsey.com/industries/public-sector/ourinsights/understanding-asean-seven-things-you-need-to-know, diakses 13 Juni 2016 Pukul 14.30 WIB.

4 ASEAN, Fact Sheet on ASEAN Community, Jakarta: ASEAN Secretariat, 2015, hlm. 2, dokumen tersedia di www.asean.org.

5 ASEAN, "ASEAN VISION 2020", http://asean.org/?static post=asean-vision-2020, diakses 13 Juni 2016 Pukul 14.00 WIB.

6 Denis Hew, (eds.), Brick by brick: the building of an ASEAN economic community, Institute of Southeast Asian Studies, Singapura: ISEAS Publishing, 2007, hlm. 2.

7 Cebu Declaration on The Acceleration of The Establishment of an Asean Community by 2015, 13 Januari 2007. 
harga yang lebih kompetitif. Hal tersebut dimungkinkan melalui skema penghilangan hambatan-hambatan perdagangan saat kegiatan ekspor-impor berlangsung, seperti misalnya tambahan pajak. ${ }^{8}$ Liberalisasi yang difasilitasi oleh Komunitas Ekonomi ASEAN menjanjikan peluang yang lebih besar bagi para pelaku ekonomi maupun bagi negara-negara ASEAN. Komunitas Ekonomi ASEAN akan memperkecil jarak pembangunan di antara negara-negara anggota ASEAN. ${ }^{9}$ Integrasi intra regional tersebut juga dapat mendorong perkembangan ekonomi ASEAN sehingga ASEAN dapat berintegrasi dengan iklim ekonomi global. Dalam hal ini ASEAN dapat menjadi kekuatan ekonomi yang seimbang dengan negara maupun organisasi regional lainnya yaitu European Union (EU), Amerika Serikat, Republik Rakyat Tiongkok (RRT), dan Jepang.

Namun demikian, usaha integrasi tersebut agaknya akan memperoleh jegalan akibat sengketa Laut Tiongkok Selatan. Sengketa Laut Tiongkok Selatan muncul pada saat negara-negara ASEAN tengah melakukan upaya integrasi baik intraregional maupun ekstra-regional. Selain terjadi saling klaim kepemilikan wilayah antar negara anggota ASEAN, Sengketa Laut Tiongkok Selatan juga melibatkan negara-negara mitra ASEAN dalam hal integrasi ke iklim ekonomi global, yaitu RRT, Amerika Serikat, dan Jepang. Dengan situasi demikian maka terjadi pertentangan antara konflik dan kooperasi.

Tak dapat dipungkiri bahwa adanya suatu konflik di antara negara-negara yang sedang bekerja sama akan berakibat buruk bagi keberlangsungan kerja sama tersebut. Hal ini berlaku juga dengan upaya integrasi yang diusung ASEAN. Sengketa internasional mengenai Laut Tiongkok Selatan akan berimplikasi pada upaya integrasi ekonomi. Dalam hal ini ASEAN sebagai organisasi regional yang anggotaanggotanya terlibat dalam sengketa di atas, selayaknya memandang sengketa Laut Tiongkok Selatan sebagai masalah kolektif yang harus diselesaikan.

Hidetaka Yoshimatsu, seorang ahli politik internasional, pada 2006 menulis sebuah artikel yang berjudul "Collective Action Problems and Regional Integration in ASEAN". Hidetaka meneliti mengenai bagaimana tindakan kolektif (collective action) dapat mendorong integrasi ekonomi. Penelitian tersebut sampai pada kesimpulan bahwa walaupun negara-negara di ASEAN tidak menginginkan adanya pembentukan organisasi supranasional untuk menyelesaikan masalah kolektif, ASEAN telah membangun secara bertahap mekanisme penegakan yang layak. Mekanisme tersebut terwujud karena ASEAN memiliki negara yang mengambil

$8 \quad$ Myrna S. Austria, "Non-tariff barriers: A challenge to achieving the ASEAN Economic Community," dalam buku ASEAN Economic Community - A Work in Progress yang disusun oleh Sanchita Basu Das, et. al. (eds), Singapura: ISEAS Publishing, 2013, hlm. 31.

9 Gap Pembangunan (development gap) timbul saat pendapatan per kapita atau perkembangan sosial lainnya antara satu negara dengan negara lainnya; Rokiah Alavi dan Aisha Ramadan, "Narrowing development gaps in ASEAN", Journal of Economic Cooperation, Volume 29, Nomor 1, 2008, hlm. 29. 
peranan vokal untuk mendorong negara-negara ASEAN lebih terintegrasi. Hal ini misalnya terlihat dari beberapa negara yang menginisiasi dan mempromosikan percepatan integrasi ekonomi. Koordinasi demikian dibutuhkan apabila ASEAN menghadapi negara di luar regional ASEAN. ${ }^{10}$

Berdasarkan latar belakang yang diuraikan di atas maka terdapat dua masalah utama yang akan ditelaah dalam tulisan ini, yaitu: (1) pengaruh sengketa Laut Tiongkok Selatan terhadap integrasi ASEAN ke iklim ekonomi global dan (2) model penyelesaian sengketa Laut Tiongkok Selatan yang dapat dicanangkan ASEAN guna mendorong integrasi ekonomi ASEAN.

Metode penelitian yang digunakan adalah metode yuridis-normatif yang juga dikenal dengan studi literatur. Sifat penelitian ini adalah deskriptif-analitis dengan menggunakan data primer dan data sekunder untuk mendeskripsikan fakta yang terjadi di lapangan. Pendeskripsian tersebut khususnya didasarkan pada material hukum primer, sekunder, maupun tersier. Metode analisis yuridis-kualitatif untuk menggambarkan dan menjelaskan hasil penelitian dalam bentuk yang tidak dapat dijabarkan dalam angka.

\section{B. Sengketa Laut Tiongkok Selatan sebagai Sengketa Internasional}

Laut Tiongkok Selatan adalah laut semi tertutup yang berada di sebelah barat Samudera Pasifik seluas 3,5 juta $\mathrm{km}^{2}$. Selain sangat vital bagi pelayaran internasional, Laut Tiongkok Selatan juga kaya akan sumber daya alam, termasuk memiliki potensi minyak dan gas bumi. ${ }^{11}$ Sengketa Laut Tiongkok Selatan merupakan sengketa kepemilikan wilayah perairan. Sengketa tersebut melibatkan setidaknya empat negara ASEAN yaitu Vietnam, Filipina, Malaysia, dan Brunei Darussalam serta satu negara non-ASEAN yaitu RRT. Perbedaan klaim dan pendapat RRT dan beberapa negara ASEAN menjurus kepada penggunaan kekuatan militer, padahal di sisi lain hubungan ekonomi antara ASEAN dan RRT sangat dekat dan strategis. ${ }^{12}$

Perbedaan klaim dan pendapat RRT dan beberapa negara ASEAN menjurus kepada penggunaan kekuatan militer. RRT merupakan pihak yang paling agresif dalam sengketa Laut Tiongkok Selatan. RRT telah membangun fasilitas militer di dua pulau yang masuk ke dalam zona yang dipersengketakan, yaitu Pulau Spartly dan Pulau Paracel. RRT juga membangun fasilitas militer berupa landasan pacu pesawat tempur dan fasilitas misil pertahanan udara di daerah gugusan pulau yang terdiri dari pulau-pulau kecil dan fitur-fitur maritim lainnya. RRT kemudian mengumumkan

10 Hidetaka Yoshimatsu, "Collective Action Problems and Regional Integration in ASEAN", Contemporary Southeast Asia: A Journal of International and Strategic Affairs, Volume 28, Nomor 1, April 2006, hlm. 115-140.

11 Putusan Permanent Court of Arbitration, Filipina vs Republik Rakyat Tiongkok: PCA Case No. 2013-19, 29 Oktober 2015, paragraf 3.

12 Leszek Buszynski dan Iskandar Sazlan, "Maritime claims and energy cooperation in the South China Sea", Contemporary Southeast Asia: A Journal of International and Strategic Affairs, Volume 29, Number 1, 2007, hlm. 143. 
peringatan untuk tidak melintas di dua daerah pulau tersebut. Tindakan RRT memicu reaksi keras dari Filipina, karena Pulau Spartly jauh lebih dekat ke Filipina dibandingkan ke RRT. Klaim RRT didasarkan pada peta yang diterbitkan pada 1940an yang disebut nine-dashed map. Filipina yang tidak dapat menerima hal terebut kemudian menjalankan strategi diplomasi untuk menyelesaikan sengketa, yakni dengan melaksanakannegosiasi bilateral dan multilateral. Namun demikian isu-isu utama masih belum terselesaikan, hingga konflik Laut Tiongkok Selatan meluas sampai dengan sekarang.

Pada akhirnya, Filipina mengajukan sengketa ke Permanent Court of Arbitration (PCA) di Den Haag, Belanda. Filipina menggunakan dasar hukum United Nations Convention on the Law of the Sea 1982 (UNCLOS 1982). Namun demikian, RRT menolak yuridiksi PCA, menunjukan keengganannya untuk menggunakan hukum internasional dalam menyelesaikan sengketa Laut Tiongkok Selatan.

Konflik semakin rumit ketika melibatkan aspek ekonomi. Amerika Serikat menjadi pihak dalam konflik Laut Tiongkok Selatan dengan mengirimkan kapal perangnya ke Laut Tiongkok Selatan menggunakan alas hak Freedom of Navigation (kebebasan berlayar). Tindakan Amerika Serikat ini dilakukan dengan alasan untuk memastikan Laut Tiongkok Selatan masih terbuka untuk seluruh kapal yang ingin melewatinya. Amerika Serikat ingin memastikan bahwa kapal-kapal dagang tidak terhambat untuk memasuki Laut Tiongkok Selatan.

Jepang juga kemudian terlibat karena pembangunan fasilitas militer Pulau Spartly dianggap akan berimplikasi pada keamanan wilayahnya. Klaim RRT atas Laut Tiongkok Selatan dianggap akan membahayakan jalur perdagangan maritim Jepang. Dengan latar belakang tersebut Jepang melakukan berbagai hal, diantaranya membangun kerja sama keamanan dengan Filipina dalam hal pemberian fasilitas persenjataan. ${ }^{13}$

Isu Laut Tiongkok Selatan sangat menarik karena merupakan isu dengan tingkat kompleksitas tinggi. Sengketa yang tidak lagi hanya tentang wilayah namun melibatkan isu sumber daya dan peran Ekonomi RRT sebagai negara yang merupakan kekuatan baru dunia dari Asia Timur. Sengketa ini juga melibatkan Amerika Serikat dan Jepang sebagai negara adikuasa yang bersaing dengan RRT. ${ }^{14}$

Selain itu RRT juga berusaha untuk mencegah Vietnam, Filipina dan Malaysia untuk melakukan eksplorasi dan pengeboran cadangan minyak dan gas bumi di wilayah yang diklaimnya. Tindakan RRT memicu reaksi dari negara-negara ASEAN

13 The Japan Times News, "Japan to supply Philippines with military equipment" http://www.japantimes.co.jp/news/2016/02/28/national/japan-to-supply-philippines-with-militaryequipment/\#.V2yAmjYkpOw, diakses 28 Februari 2016.

14 Selengkapnya lihat Alice D. Ba, "Staking claims and making waves in the South China Sea: how troubled are the waters?", Contemporary Southeast Asia, A Journal of International and Strategic Affairs, Volume 33, Number 3, 2011, hlm. 269-291. 
serta negara lainnya yaitu Amerika Serikat dan Jepang. Permasalahan eksplorasi minyak dan gas bumi di Laut Tiongkok Selatan dapat memperparah konflik. Permintaan pasar dunia akan gas bumi membuat RRT di masa yang akan datang memandang sumber minyak dan gas bumi untuk semakin memperkuat ekonominya. RRT telah melakukan upaya pemenuhan energinya dengan menandatangani perjanjian jangka panjang dengan Venezuela, Nigeria, dan Sudan. Potensi gas dan minyak bumi di Laut Tiongkok Selatan kemungkinan akan menjadi salah satu kepentingan nasional RRT yang mereka lindungi. ${ }^{15}$

\section{Sengketa Laut Tiongkok Selatan sebagai Faktor Penghambat Integrasi ASEAN ke Iklim Ekonomi Global}

Hukum internasional memiliki karakter khusus yang berbeda dengan hukum nasional. Tidak seperti hukum nasional, hukum internasional tidak memiliki lembaga yang lebih tinggi dari negara-negara lain, dalam hal ini disebut lembaga supranasional. Dengan demikian, tidak ada pihak yang dapat memaksa suatu negara untuk tunduk pada hukum internasional apabila negara tersebut tidak dengan sendirinya mengikatkan diri. Oleh karena itu, hukum internasional disebut dengan law of coordination.

Terlebih lagi, seolah sudah sifat alamiah dari negara adi kuasa untuk cenderung dapat memaksakan tindakannya ke negara lain, bahkan tanpa menghiraukan hukum internasional. Salah satu yang berperan dalam menciptakan kondisi tersebut adalah kemampuan ekonomi. Sebelum kekuatan ekonomi RRT sebesar saat ini, ASEAN yang mencanangkan adanya integrasi politik setidaknya pernah berhasil dalam menekan RRT untuk menyetujui ASEAN Declaration on the Conduct of Parties in the South China Sea untuk meredakan ketegangan akibat sengketa mengenai wilayah tersebut. Instrumen hukum internasional tersebut menyatakan bahwa para pihak akan menyelesaikan masalah sengketa wilayah menggunakan cara-cara damai, tanpa penggunaan kekuatan militer. ASEAN Declaration on th Conduct of Parties in the South China Sea setidaknya telah menciptakan suasana aman dan kondusif antara ASEAN-RRT. Suasana kondusif tersebut memperlancar integrasi regional antara RRT dan ASEAN, melalui berbagai program ekonomi, perdagangan, infrastruktur, dan budaya. ${ }^{16}$

Terdapat dua hambatan utama yang muncul dari adanya sengketa internasional Laut Tiongkok Selatan terhadap upaya integrasi ASEAN. Pertama adalah masalah interkoneksi perdagangan dan kedua adalah adanya upaya RRT

15 Leszek Buszynski, "Rising Tensions in the South China Sea: Prospects for a Resolution of the Issue", Security Challenges, Volume 6, Number 2, 2010, hlm. 89.

16 Peter Dutton, "Three disputes and three objectives: China and the South China Sea," Naval War College Review, Volume 64, Number 4, 2011, hlm. 43. 
untuk memecah belah ASEAN dalam upaya ASEAN menyelesaikan isu Laut Tiongkok Selatan. Berikut akan dijelaskan lebih lanjut.

Pertama, masalah interkoneksi perdagangan. Interkoneksi merupakan hal yang penting dalam peradangan internasional, sedangkan Laut Tiongkok Selatan adalah jalur strategis perdagangan di ASEAN. Tak hanya dengan RRT, Laut Tiongkok Selatan juga merupakan jalur pelayaran dari ASEAN ke Amerika Serikat, Jepang, maupun Eropa. Eskalasi kegiatan militer yang meningkat di Laut Tiongkok Selatan akan berdampak buruk bagi kegiatan ekonomi di Laut Tiongkok Selatan. Tindakan RRT yang mengeluarkan larangan untuk mendekati Pulau Spartly dan Paracel merupakan indikator nyata bahwa hambatan-hambatan akan muncul di jalur pelayaran internasional. Hal tersebut merupakan salah satu alasan yang dikemukakan oleh Amerika Serikat dan Jepang sehingga terlibat dalam sengketa Laut Tiongkok Selatan. Secara teknis keterhubungan ekonomi ASEAN dengan negara-negara di luar ASEAN menghendaki adanya Laut Tiongkok Selatan yang aman dan damai.

Kedua, upaya RRT dalam memecah ASEAN. RRT memiliki strategi untuk memecah belah integrasi ASEAN dalam menghadapi sengketa Laut Tiongkok Selatan. RRT cenderung bertujuan untuk memisahkan negara-negara yang terlibat sengketa Laut Tiongkok Selatan dari negara ASEAN yang tidak terlibat. Posisi semacam ini akan menghasilkan keuntungan posisi RRT dalam sengketa Laut Tiongkok Selatan. Dalam hal ini, Leszek Buszynski menyatakan bahwa: ${ }^{17}$

"The Chinese, in any case, have proposals of their own to involve ASEAN claimants in functional cooperation which would avoid multilateral negotiations with ASEAN or the ARF. They intend to separate the ASEAN claimants from ASEAN as an organisation, and from the external powers involved in the ARF, which would leave them in a position of advantage."

Dasar dari pernyataan di atas diantaranya muncul karena adanya usulan RRT untuk membentuk South China Sea Economic Cooperation Organization (SCSEC) dan Pan Beibu Gulf(Gulf of Tonkin) Economic Cooperation Forum.

Usulan pembentukan SCSEC muncul saat konferensi antara RRT dan para peneliti dari Asia Tenggara di Haikou, Provinsi Hainan, RRT pada bulan Maret 2008. Konferensi ini adalah konferensi yang digagas pemerintah lokal RRT dan melibatkan perwakilan dari Brunei Darussalam, Malaysia, Filipina, Vietnam, dan Singapura. Di lain pihak, pemerintah lokal yang hadir dari RRT adalah pemerintahan Provinsi Hainan, Guangdong, dan Guangxi. Konferensi tersebut mengusulkan adanya peningkatan perdagangan dan investasi untuk memperkuat kerja sama di bidang

17 Leszek Buszynski, Op.cit. hlm. 85. 
infrastruktur, pariwisata, dan pertanian. Dapat terlihat dari negara-negara peserta tersebut adalah bukan dari seluruh negara ASEAN. Implikasi yang dapat terjadi adalah bahwa masalah Laut Tiongkok Selatan akan dipandang sebagai masalah negara-negara itu saja, bukan masalah ASEAN. ${ }^{18}$

RRT juga menggunakan Pan Beibu Gulf (Gulf of Tonkin) Economic Cooperation Forum untuk membahas masalah-masalah maritim termasuk sengketa Laut Tiongkok Selatan. Forum pertama diselenggarakan pada bulan Juli 2006 yang melibatkan negara-negara anggota ASEAN termasuk Korea Selatan. Forum pertama Pan Beibu Gulf (Gulf of Tonkin) Economic Cooperation diselenggarakan dengan tujuan untuk membangun ikatan yang lebih kuat dalam hal kerja sama ASEANTiongkok. ${ }^{19}$ Forum tersebut berlanjut dan sampai saat ini forum ke-8 telah dilaksanakan di Nanning, RRT. Forum tersebut dihadiri oleh RRT, Brunei Darussalam, Indonesia, Vietnam, Malaysia, Filipina, dan Singapura. ${ }^{20}$

Dalam melaksanakan kerja sama kemaritiman, RRT hanya sebatas membangun upaya diplomatik dengan beberapa negara ASEAN dan cenderung menghindari negosiasi pada tingkat ASEAN maupun ASEAN Regional Forum (ARF). ARF sendiri merupakan forum dialog yang dibentuk pertama kali pada tahun 1994 yang bertujuan mendiskusikan dan mengonsultasikan isu-isu politik serta keamanan di kawasan Asia Pasifik. ${ }^{21}$ Melalui forum-forum tersebut RRT melakukan kerja sama kemaritiman sebagai upaya untuk mencegah negara-negara tersebut untuk melakukan negosiasi di bawah bendera ASEAN. Melalui cara-cara pemisahan tersebut, posisi RRT akan semakin dominan dibanding bernegosiasi langsung dengan ASEAN. ${ }^{22}$

Di sisi lain, negara-negara di bawah ASEAN akan memiliki posisi tawar yang lebih besar dibanding menghadapi RRT secara terpisah. Posisi tersebut bukan dalam hal kekuatan militer, namun ekonomi. ASEAN tidak perlu memiliki kekuatan angkatan laut yang besar untuk menandingi kekuatan angkatan laut RRT yang saat ini menduduki dua pulau di Laut Tiongkok Selatan. Apabila kontak senjata dilakukan RRT, maka hal tersebut akan memicu risiko yang besar bagi hubungan ekonomi ASEAN-RRT karena akan mempengaruhi investasi dan perdagangan yang merugikan RRT. Hal tersebut sejalan dengan apa yang dikatakan Leszek Buszynski: ${ }^{23}$

"By creating ... capability which could defend their already occupied

islands in the South China Sea claimants would create unacceptable

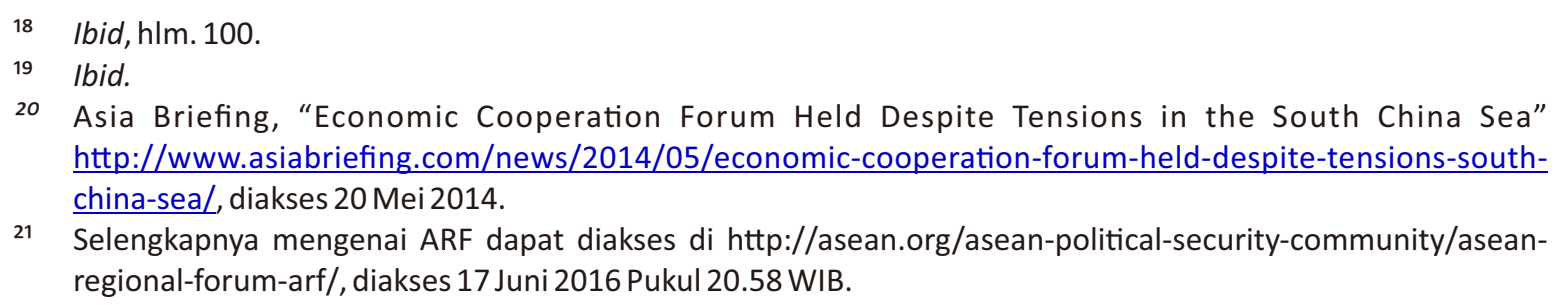
http://www.asiabriefing.com/news/2014/05/economic-cooperation-forum-held-despite-tensions-southchina-sea/, diakses 20 Mei 2014.

21 Selengkapnya mengenai ARF dapat diakses di http://asean.org/asean-political-security-community/aseanregional-forum-arf/, diakses 17 Juni 2016 Pukul 20.58 WIB.

22 Ibid.

23 Ibid. 
risks for China in the resort to force. Any naval clash in the area would have immediate repercussions for China's relationship with ASEAN and Taiwan and would affect investor confidence in the region from which China would suffer."

Terdapat kemungkinan bahwa konsekuensi di atas mengharuskan RRT untuk menahan diri menggunakan senjata militer dan mau tidak mau harus memilih strategi kooperatif. Dengan demikian forum-forum yang digagas RRT akan menghasilkan kemunduran dalam integrasi ASEAN, sedangkan keadaan politikkeamanan yang terintegrasi merupakan landasan bagi kesuksesan integrasi ekonomi.

\section{Model Penyelesaian Sengketa Internasional di ASEAN Untuk Mendorong Integrasi Ekonomi ASEAN}

Penyelesaian secara hukum yang saat ini dipilih oleh Filipina untuk menyelesaikan sengketa Laut Tiongkok Selatan adalah melalui PCA. Tindakan tersebut hanya dilakukan oleh Filipina saja, padahal Sengketa Laut Tiongkok Selatan secara keseluruhan tidak hanya melibatkan Filipina. Sebagian besar negara-negara yang bersengketa masalah Laut Tiongkok Selatan adalah anggota ASEAN. Dengan demikian sebaiknya ASEAN terus mengupayakan penyelesaian sengketa secara damai walaupun Filipina menempuh prosedur di PCA.

Apabila dapat diumpamakan, dalam hal kekuatan politik maupun ekonomi, sengketa antara RRT dan Filipina seperti halnya peperangan antara David vs Goliath. Hubungan RRT yang dekat dengan Amerika Serikat digunakan oleh Filipina untuk mengimbangi kekuatan politik RRT, namun hal tersebut tidak akan berlangsung selamanya. ASEAN harus mempromosikan integrasi dan kooperasi untuk menyeimbangkan kekuatan. Simon Long menyatakan bahwa: "China's territorial claims ... are best tackled by multilateral regional forum. American umbrella still keeps the region safe. But in will not be rainproofforever."24

Model yang dapat digunakan oleh ASEAN untuk menyelesaikan masalah Laut Tiongkok Selatan adalah seperti yang digambarkan dalam bagan 1 di bawah. Bagan tersebut merupakan sebuah fishbone diagram yang menginventarisasi faktor-faktor apa saja yang diperlukan untuk dapat mencapai penyelesaian sengketa Laut Tiongkok Selatan oleh ASEAN. Keseluruhan faktor yang digambarkan kemudian akan membawa pada tujuan ASEAN untuk dapat berintegrasi ke Iklim ekonomi global.

24 Simon Long dalam, Yoram Z. Haftel, Regional Economic Institutions and Conflict Mitigation: Design Implementation, and the Promise of Peace, Amerika Serikat: University of Michigan Press, 2012, hlm. 3. 


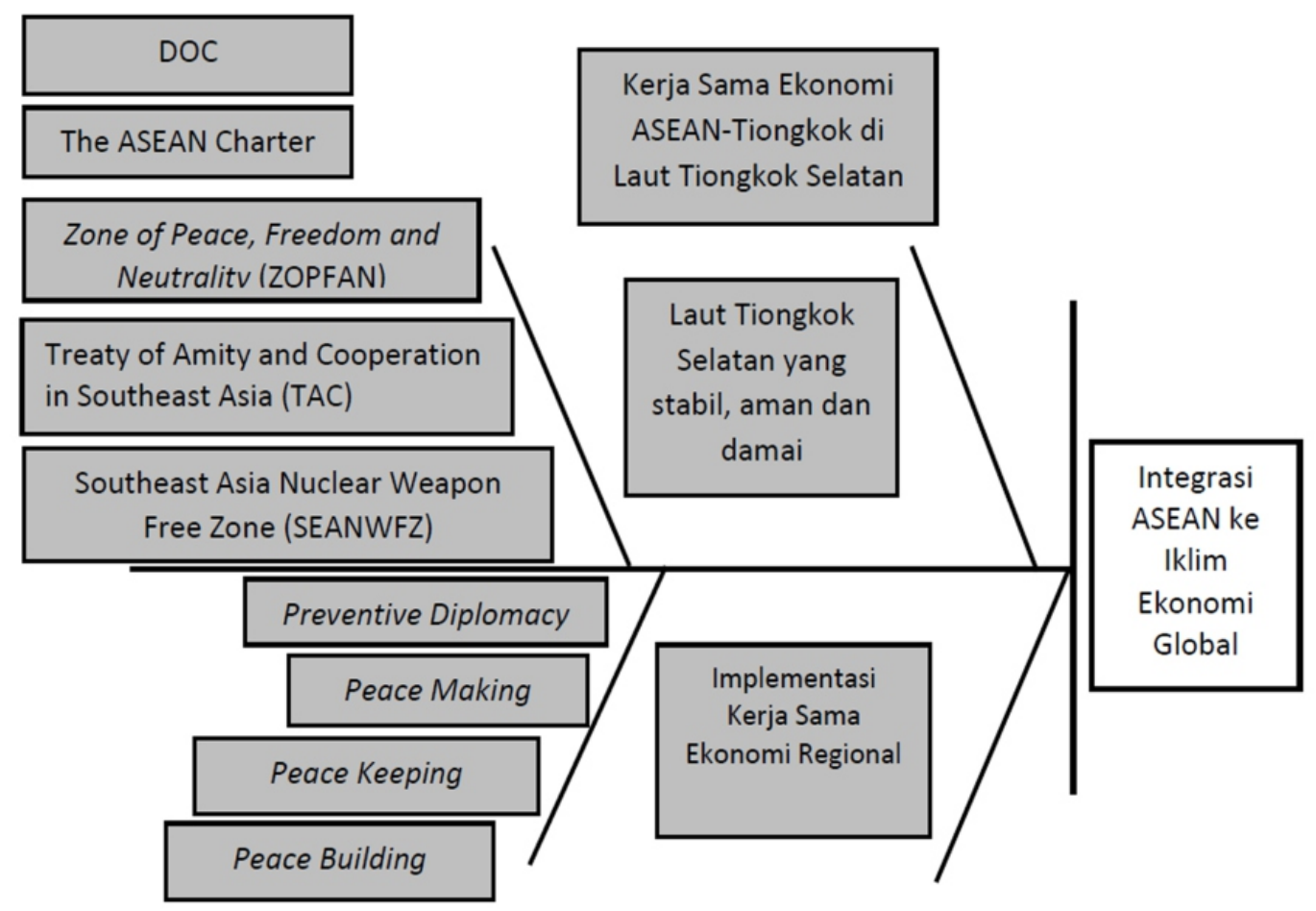

\section{Bagan 1:}

\section{Fishbone Diagram Penyelesaian Sengketa Laut Tiongkok Selatan Guna Mencapai Integrasi ASEAN ke Iklim Ekonomi Global}

Charter of The Association of Southeast Asian Nation 2007 (ASEAN Charter 2007) tidak dapat memberikan mekanisme penyelesaian sengketa yang sepenuhnya dapat digunakan dalam menyelesaikan sengketa Laut Tiongkok Selatan. Untuk itu ASEAN Charter 2007 perlu dilengkapi dengan berbagai instrumen hukum lainnya. Sejak pembentukannya, ASEAN sepertinya tidak bermaksud untuk menggunakan mekanisme penyelesaian sengketa di ASEAN Charter 2007 tersendiri. Pembentukan mekanisme tersebut ditengarai hanya bertujuan sebagai legitimasi internasional ASEAN sebagai organisasi internasional, karena setiap organisasi regional memiliki mekanisme penyelesaian sengketa sendiri. Berbeda dengan Uni Eropa maupun North American Free Trade Agreement yang membentuk mekanisme penyelesaian sengketa dengan latar belakang untuk menyelesaikan masalah-masalah sengketa yang timbul karena meningkatnya hubungan dagang di internal regionalnya. ${ }^{25}$

25 Leon Kanthak, "Explaining Differences in the Institutional Design of ASEAN and NAFTA", dalam buku Roads to Regionalism: Genesis, Design, and Effects of Regional Organizations yang disusun oleh Tanja A. Borzel et.al. (eds), Amerika Serikat dan Inggris: Ashgate Pubishing, 2012, hlm. 109-111. 
Untuk mengatasi kekurangan pengimplementasian penyelesaian sengketa menggunakan mekanisme ASEAN Charter 2007, kerja sama politik dan keamanan sangat vital bagi negara-negara anggota ASEAN untuk meredam dan mencegah sengketa internasional. Pada 1971, the Zone of Peace, Freedom and neutrality (ZOPFAN) ditandatangani oleh negara-negara anggota ASEAN. ZOFAN ditandatangani untuk menjamin terbebasnya ASEAN dari intervensi kekuatankekuatan luar. ZOFAN juga bertujuan untuk memperluas kerja sama yang akan berkontribusi untuk kekuatan, solidaritas, dan hubungan baik di antara negaranegara anggota ASEAN. ZOFAN merupakan adalah dokumen pertama yang menetapkan visi ASEAN dalam hal kooperasi regional. ${ }^{26}$

Sembilan tahun setelah menandatangani ZOFAN, para pemimpin ASEAN berkumpul di Bali pada 24 Februari 1976. Negara-negara anggota ASEAN menandatangani tiga instrumen hukum penting yang membentuk kerangka kerja sama politik-keamanan di regional ASEAN. Instrumen-instrumen hukum tersebut adalah Treaty of Amity and Cooperation (TAC) in Southeast Asia, Declaration of ASEAN Concord, Agreement on the Establishment of the ASEAN Secretariat. ${ }^{27}$

TAC yang ditandatangani pada 1976 merupakan pedoman untuk melaksanakan hubungan-hubungan antar negara ASEAN. TAC memberlakukan prinsip-prinsip yang mendorong terciptanya hubungan antar negara yang harmonis. Prinsip-prinsip tersebut diantaranya adalah mutual respect of sovereignty and independence of all nations, non-interference to internal affairs of one another, dan settlement of disputes by peaceful means.

Selain itu, negara-negara ASEAN telah menandatangani South Asian NuclearWeapon-Free-Zone (SEANWFZ) pada 15 Desember 1995 di Bangkok, Thailand. Perjanjian internasional tersebut mengatur pelucutan dan pelarangan penggunaan senjata nuklir di ASEAN. Melalui perjanjian ini, Asia Tenggara menjadi zona bebas senjata nuklir ataupun senjata pemusnah masal lainnya. Dengan demikian, ASEAN turut berkontribusi untuk memperkuat keamanan dan perdamaian internasional secara keseluruhan. ${ }^{28}$

Instrumen-instrumen hukum internasional tersebut di atas memberikan landasan bagi ASEAN untuk dapat melakukan upaya integrasi politik-keamanan dalam hal penyelesaian sengketa secara damai. Terlebih, negara-negara ASEAN sudah memberikan komitmen untuk menyelesaikan masalah Laut Tiongkok Selatan dengan menandatangani Declaration on the South China Sea pada 1992. Deklarasi tersebut menegaskan posisi ASEAN untuk menyelesaikan sengketa Laut Tiongkok Selatan secara damai.

\footnotetext{
26 ASEAN, ASEAN Security Outlook 2015, Malaysia: ASEAN, 2015, hlm. 12, http://www.asean.org/wpcontent/uploads/2015/12/ASEAN-SECURITY-OUTLOOK-2015.pdf, diakses pada 17 Juni 2016, pukul 6.00 WIB.

27 Ibid., hlm. 23.

28 Ibid.
} 
Kemudian, pada 4 November 2002 ASEAN bersama sama dengan RRT menandatangani Declaration of Conduct of South China Sea (DOC) yang menegaskan komitmen ASEAN-Tiongkok untuk menyelesaikan sengketa Laut Tiongkok Selatan dengan cara damai dan berdasarkan hukum internasional. DOC mendorong masing-masing pihak untuk saling menahan diri untuk tidak melakukan hal-hal yang dapat memperumit dan mempengaruhi perdamaian dan stabilitas di wilayah tersebut. DOC juga dimaksudkan untuk mengintensifkan upaya untuk mencari cara penyelesaian sengketa secara damai.

Pada Juli 2011 The Guidelines for the implementation of the DOC disetujui dalam forum the ASEAN-Tiongkok Ministerial Meeting di Bali, Indonesia. Pada Juli 2012, sebagai hasil dari konsultasi ASEAN Foreign Ministers, ASEAN mendeklarasikan ASEAN's Six Point Principles on the South China Sea. Enam prinsip tersebut dimaksudkan untuk mempercepat dan mengintensifkan penyelesaian isu Laut Tiongkok Selatan. Keseluruhan isi dari instrumen-instrumen hukum tersebut di atas harus sejalan dengan TAC 1976 dan ASEAN Charter 2007.

Upaya ASEAN dengan menghasilkan berbagai instrumen hukum di atas tampaknya hanya berhasil menahan RRT untuk sementara. Apabila ditelaah, sejak pertengahan 1990-an RRT telah mengimplementasikan strategi untuk menunda dan memperlambat penyelesaian sengketa Laut Tiongkok Selatan. Tujuan dari strategi tersebut adalah untuk mengonsolidasi dan menguatkan dasar klaim RRT, termasuk proyek pembangunan infrastruktur di daerah yang dipersengketakan. Kemudian memasuki periode tahun 2000-an, intensitas RRT untuk semakin menunjukkan klaimnya pada Laut Tiongkok Selatan mengikat dengan dilakukannya pendekatan secara diplomatik maupun menggunakan kekuatan militer. ${ }^{29} \mathrm{Hal}$ ini membuat posisi negara-negara ASEAN yang baik secara kekuatan ekonomi maupun militer relatif di bawah RRT menjadi terancam.

ASEAN diharapkan dapat memberikan pengaruhnya lebih luas, tidak hanya untuk hubungan antar negara ASEAN namun juga terhadap partner internasionalnya. ASEAN dapat terus membuka dialog dan mendorong penyelesaian sengketa dengan cara damai untuk masalah Laut Tiongkok Selatan. Dengan demikian, ASEAN dapat menghasilkan perubahan pada politik internasional. Capaian tersebut hanya dapat dicapai dengan prinsip kolektivitas yang tercermin dalam ASEAN Political-Security Community.

Pembukaan ASEAN Charter 2007 menyatakan bahwa ASEAN berkomitmen untuk mengintensifkan bangunan masyarakat melalui peningkatan kerja sama regional dan integrasi, khususnya melalui pembentukan Komunitas ASEAN, termasuk Komunitas Politik-Keamanan ASEAN. Inisiatif pembentukan Komunitas

29 M. Taylor Fravel, "China's strategy in the South China Sea", Contemporary Southeast Asia: A Journal of International and Strategic Affairs, Vomume 33, Number 3, 2011, hlm. 292-319. 
Politik-Keamanan ASEAN dibahas pada tahun 2003. ASEAN juga telah menyadari bahwa iklim politik dan keamanan yang kondusif di dalam ASEAN akan memberikan dasar yang kuat bagi terciptanya kerja sama ekonomi. Hal tersebut merupakan hasil dari ASEAN Concord II. ${ }^{30}$

Dengan demikian, porsi perhatian ASEAN harus diberikan pada bidang Integrasi Politik-Keamanan di ASEAN seiring dengan porsi perhatian pada integrasi ekonomi. Hal ini dikarenakan kestabilan politik-keamanan menjadi dasar keberhasilan integrasi ekonomi. Tantangan ke depan yang saat ini terlihat dari isu Laut Tiongkok Selatan adalah bagaimana ASEAN dapat berperan untuk turut menjaga hubungan degan negara di luar ASEAN. Bukan hanya di bidang ekonomi namun juga dalam hal hubungan politik-keamanan di luar ASEAN. ASEAN dalam hal ini harus kembali berkooperasi dengan RRT untuk mengembalikan situasi damai di Laut Tiongkok Selatan. Secara internal ASEAN perlu melakukan lagi upaya penyelesaian sengketa antar negara ASEAN itu sendiri dan upaya penyelesaian sengketa dengan RRT. Hal ini hanya dapat dicapai dengan integrasi politik-keamanan di ASEAN.

Keadaan politik-keamanan yang stabil di ASEAN merupakan fondasi yang solid untuk menciptakan perkembangan ekonomi. Julia Gray mengategorikan organisasi ekonomi regional ke dalam tiga keadaan, yaitu: (1) organisasi internasional ekonomi yang berakhir dengan keluarnya para anggotanya; (2) organisasi internasional yang seolah menjadi mayat hidup, yaitu organisasi internasional tersebut hanya sebuah nama saja karena tidak mampu beroperasi efektif; dan (3) organisasi regional yang hidup dan berfungsi efektif. ${ }^{31}$ Dalam hal ini ASEAN dituntut untuk aktif berperan dalam menciptakan kondisi politik-keamanan yang stabil guna terwujudnya ASEAN sebagai organisasi regional yang hidup dan berfungsi efektif.

Untuk menjadi organisasi regional yang hidup dan berfungsi efektif, maka ASEAN dapat menggunakan empat kelompok tindakan seperti halnya Perserikatan Bangsa-Bangsa (PBB). Kelompok tindakan tersebut adalah Preventive Diplomacy (Diplomasi Pencegahan), Peace Making (Pembawa Perdamaian), Peace Keeping (Penjaga Perdamaian), dan Peace Building (Pembangun Perdamaian). ${ }^{32}$ Kelompok tindakan tersebut memang kelompok tindakan yang seyogyanya dimiliki oleh PBB, namun demikian sejak lama Boutros Boutros-Ghali sudah menyadari bahwa organisasi regional juga memiliki potensi untuk melaksanakan kelompok tindakan-

30 Declaration of ASEAN Concord II (Bali Concord II) 7 Oktober 2003.

31 Julia Gray. "Life, Death, or Zombies? The Endurance of Inefficient Regional Economic Organizations", disampaikan pada Political Economy of International Organizations Conference, Princeton University, 2012, h I m. i. htt p://www.princeton.edu/politics/about/filerepository/public/Gray_zombies_princeton_oct2012.pdf, diakses 23 April 2016 Pukul 13.00 WIB.

32 Boutros Boutros-Ghali dalam buku Hukum Penyelesaian Sengketa Internasional yang disusun oleh Huala Adolf, Jakarta: Sinar Grafika, hlm. 95. 
tindakan tersebut. ${ }^{33}$ Berikut kelompok tindakan yang dapat dilakukan oleh ASEAN:

1. Preventive Diplomacy (Diplomasi Pencegahan)

Preventive Diplomacy dapat diartikan sebagai suatu tidakkan pencegahan yang dilakukan suatu entitas guna mencegah meluasnya suatu sengketa, atau membatasi perluasan suatu sengketa. ${ }^{34}$ Pasal 13 TAC mengharuskan negara-negara di ASEAN untuk berusaha mencegah timbulnya sengketa di antara mereka dan sebisa mungkin menahan diri untuk tidak menggunakan kekerasan. ${ }^{35}$ Dalam konteks Laut Tiongkok Selatan, negara-negara ASEAN tidak disarankan untuk menggunakan kekuatan militer untuk menghadapi intimidasi RRT di Laut Tiongkok Selatan.

2. Peace Making (Pembawa Perdamaian)

Tindakan peace making merupakan tindakan untuk membawa para pihak yang bersengketa agar mencapai kesepakatan melalui cara-cara damai. ${ }^{36}$ Dalam hal ini, Pasal 14 TAC membuka kemungkinan untuk menyelesaikan sengketa melalui pembentukan The High Council yang terdiri dari setiap negara anggota ASEAN. The High Council memiliki wewenang untuk menggunakan jasa baik, mediasi, penyelidikan atau konsiliasi, apabila para pihak menyetujuinya. Sayangnya untuk konflik Laut China Selatan, mekanisme pembentukan The High Council kurang pas untuk dilakukan. The High Council didesain untuk menyelesaikan sengketa intra regional ASEAN, sedangkan sengketa Laut Tiongkok Selatan melibatkan negara di luar ASEAN. Namun demikian, ASEAN memiliki ASEAN Regional Forum (ARF).

ASEAN Ministerial Meeting yang diselenggarakan di Singapura 23-25 Juli 1993, menyetujui untuk membentuk ARF. Tujuan ARF adalah untuk mengembangkan dialog dan konsultasi dalam hal isu-isu politik dan keamanan yang menjadi perhatian bersama. Selain sebagai upaya pelaksanaan preventive diplomacy, ARF juga dapat menjadi peace making dengan menjadi forum dialog dan kerja sama yang saling membangun antara ASEAN dan partner negara lainnya. Seluruh pihak yang terlibat dalam isu Laut Tiongkok Selatan adalah partner dalam ARF, termasuk RRT, Amerika Serikat, Jepang, dan India. ${ }^{37}$ Dengan demikian ASEAN dapat menggunakan ARF untuk terus mengupayakan perdamaian di Laut Tiongkok Selatan.

\section{Peace Keeping (Penjagaan Perdamaian)}

Ralph Emmers, "Regional Organisations and Peacekeeping: a Study of the ARF" Dalam buku Forces for Good: Cosmopolitan Militaries in the Twenty-first Century yang disusun oleh Lorraine Elliott dan Graeme Cheeseman (eds.), Manchester dan New York: Manchester University Press, 2004, hlm. 134.

36 Ibid, hlm. 96.

37 ASEAN, "About The ASEAN Regional Forum", http://aseanregionalforum.asean.org/about.html, diakses 23 April 2016 Pukul 9.00 WIB. 
Penjagaan perdamaian dilakukan dengan mengerahkan kehadiran organisasi internasional secara fisik untuk memelihara perdamaian. Hal ini harus dilakukan dengan kesepakatan para pihak yang berkepentingan. ${ }^{38}$ Contoh tindakan penjagaan perdamaian adalah pengerahan pasukan penjaga perdamaian oleh PBB ke daerah konflik. $^{39}$

Saat ini kekuatan militer Tiongkok, Amerika Serikat, Jepang ,dan beberapa negara ASEAN telah hadir di Laut Tiongkok Selatan. Kendati demikian, penggunaan kekuatan militer suatu negara untuk menyerang negara lain belum terjadi. Situasi ini merupakan situasi yang genting dan mengancam perdamaian di regional ASEAN. ASEAN dan para partner konsultasinya saat ini belum membentuk suatu multilateral peace keeping operation atau operasi penjagaan perdamaian multilateral untuk menjamin agar para pihak tidak menggunakan kekuatan militer. ARF merupakan forum yang dapat menjadi forum inaugurasi apabila ASEAN berkeinginan untuk mengusulkan adanya operasi penjagaan perdamaian.

4. Peace Building (Pembangunan Perdamaian)

Peace Building adalah tindakan untuk mengidentifikasi dan mendukung strukturstruktur yang ada guna memperkuat perdamaian dan mencegah perdamaian yang telah berhasil ditempuh berubah kembali menjadi konflik. ${ }^{40}$ Sengketa Laut Tiongkok Selatan yang tengah terjadi telah menghalangi pemanfaatan sumber daya hidrokarbon di sana. Harga minyak dunia yang cenderung naik dan kebutuhan energi yang besar dari RRT telah menstimulasi kepentingan yang lebih besar untuk mengeksploitasi cadangan minyak di Laut Tiongkok Selatan. Di tengah ketidakpastian, negara-negara di ASEAN telah bekerja sama dengan perusahaanperusahaan dalam hal eksplorasi dan pengeboran minyak. Kerja sama dengan perusahaan minyak nasional RRT merupakan prospek besar untuk mempertahankan keamanan, bahkan ketika penyelesaian Sengketa Laut Tiongkok Selatan belum dapat dicapai. Kerja sama di bidang energi dapat menstabilkan situasi di Laut Tiongkok Selatan karena tuntutan adanya situasi yang aman untuk pelaksanaan eksplorasi dan pengeboran minyak. ${ }^{41}$ Selama situasi aman telah tercapai, maka ASEAN dapat mendorong lebih jauh penyelesaian sengketa Laut Tiongkok Selatan terkait nine-dashed line.

Secara hukum, penyelesaian sengketa Laut Tiongkok Selatan akan melibatkan norma-norma yang ada di dalam United Nations Convention on the Law of the Sea 1982 (UNCLOS 1982). Berdasarkan UNCLOS 1982 para pihak memiliki pilihanpilihan penyelesaian sengketa. Namun demikian, RRT tidak berkeinginan untuk

\footnotetext{
Ibid.

Ibid.

lbid., hlm. 97.

Leszek Buszynski dan Iskandar Sazlan, Loc.cit.
} 
menyatakan bahwa nine-dashed line yang digunakannya untuk mengklaim Laut Tiongkok Selatan sesuai dengan UNCLOS 1982.

RRT dan pihak lainnya yang menggunakan penyelesaian sengketa dengan cara hukum akan menggunakan Pasal 74 dan 83 UNCLOS 1982. Kaidah-kaidah tersebut digunakan untuk menyelesaikan masalah zona ekonomi eksklusif dan landas kontinen yang saling tumpang tindih antara para pihak. Kaidah tersebut memberikan ruang bagi para pihak untuk mengadakan perjanjian garis batas zona ekonomi eksklusif dan landas kontinen. Apabila tidak tercapai maka para pihak wajib menyelesaikan sengketanya dengan cara damai. ${ }^{42}$ Para pihak memiliki pilihan untuk menyelesaikan sengketa di International Tribunal for the Law of the Sea (ITLOS), Mahkamah Internasional, atau a special arbitral tribunal. ${ }^{43}$ Para pihak bebas memilih salah satu dari cara tersebut, namun sebelumnya para pihak harus terlebih dahulu melakukan mediasi dengan cara damai. Dalam hal, ini ASEAN perlu melanjutkan upayanya untuk menjadi mediator yang baik bagi para pihak yang bersengketa di Laut Tiongkok Selatan.

Selain empat tindakan di atas, sebenarnya terdapat satu kelompok tindakan lagi yang dapat dikategorikan sebagai upaya menciptakan perdamaian dan keamanan internasional, yaitu Peace Enforcement (Penegakan Perdamaian). Istilah tersebut merujuk pada wewenang organisasi internasional untuk menjatuhkan sanksi, misalnya PBB melalui Dewan Keamanan dapat menerapkan sanksi ekonomi, politik dan militer. ${ }^{44}$ Sayangnya ASEAN belum memiliki organ yang berfungsi melaksanakan Peace Enforcement seperti halnya PBB. Organ-organ ASEAN berupa ASEAN Summit, ${ }^{45}$ ASEAN Coordinating Council, ${ }^{46}$ ASEAN Community Councils, ${ }^{47}$ Secretary-General of ASEAN, ${ }^{48}$ dan lain sebagainya, tidak dibekali tugas dan wewenang yang secara tegas diberikan wewenang untuk dapat menjatuhkan sanksi politik, militer, bahkan ekonomi sekalipun.

\section{E. Penutup}

Sengketa Laut Tiongkok Selatan dapat menjadi malapetaka bagi integrasi yang dicanangkan ASEAN ke iklim ekonomi global. Perkembangan sengketa ini melibatkan tiga negara partner dalam perdagangan ASEAN yaitu RRT, Amerika Serikat, dan Jepang. Kondisi politik dan keamanan yang tidak stabil di Laut Tiongkok Selatan akan berimplikasi buruk bagi integrasi ekonomi, karena kondisi politik dan keamanan regional yang stabil merupakan fondasi bagi integrasi ekonomi. Terlebih

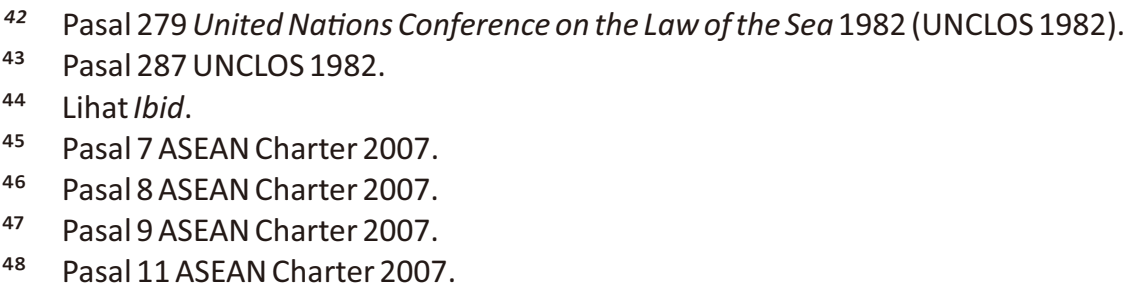


lagi RRT cenderung untuk menghindari negosiasi pada tingkat ASEAN. Untuk mengatasi hal ini ASEAN dengan dasar instrumen-instrumen hukum yang telah dimilikinya dapat melakukan revitalisasi terhadap empat kelompok tindakan, yaitu: preventive diplomacy, peace making, peace building, dan peace keeping. Revitalisasi tersebut juga dapat melibatkan ARF karena para pihak yang bersengketa merupakan partner dalam ARF. Situasi Laut Tiongkok yang stabil, aman, dan damai akan memuluskan jalan ASEAN menyelenggarakan integrasi ekonomi regional dan pada akhirnya akan sampai pada integrasi ke iklim ekonomi global.

\section{Daftar Pustaka}

\section{Buku}

ASEAN, Fact Sheet on ASEAN Community, ASEAN Secretariat, Jakarta, 2015.

Das, Sanchia Basu, et.al. (eds), ASEAN Economic Community - A Work in Progress, ISEAS Publishing, Singapura, 2013.

Hew, Denis, (eds.), Brick by brick: the building of an ASEAN economic community. Institute of Southeast Asian Studies, ISEAS Publishing, 2007.

Elliott, Lorraine dan Cheeseman, Graeme (eds.), Forces for Good: Cosmopolitan Militaries in the Twenty-first Century, Manchester University Press, Manchester dan New York, 2004.

Haftel, Yoram Z., Regional Economic Institutions and Conflict Mitigation: Design Implementation, and the Promise of Peace, University of Michigan Press, Amerika Serikat, 2012.

Huala Adolf, Hukum Penyelesaian Sengketa Internasional, Sinar Grafika, Jakarta, 2014.

Tanja A. Borzel, Tanja A., et.al. (eds), Roads to Regionalism: Genesis, Design, and Effects of Regional Organizations, Ashgate Pubishing, Amerika Serikat dan Inggris, 2012.

\section{Dokumen Lain}

A S E A , "A b o ut The ASEAN Region a Forum", http://aseanregionalforum.asean.org/about.html, diakses 23 April 2016 Pukul 9.00 WIB.

"ASEAN Security Outlook 2015", Malaysia: ASEAN, 2015, http://www.asean.org/wp-content/uploads/2015/12/ASEAN-SECURITYOUTLOOK-2015.pdf, diakses pada 17 Juni 2016, pukul 6.00 WIB.

, "ASEAN Member States", http://asean.org/asean/asean-member-states/, diakses 13 Juni 2016 Pukul 14.00 WIB.

, “ASEAN VISION 2020", http://asean.org/?static_post=asean-vision-2020/, diakses 13 Juni 2016 Pukul 14.00 WIB. 
Asia Briefing, "Economic Cooperation Forum Held Despite Tensions in the South China Sea" http://asiabriefing.com/news/2014/05/economic-cooperationforum-held-despite-tensions-south-china-sea/, 20 Mei 2014.

Asean Regional Forum, http://asean.org/asean-political-securitycommunity/asean-regional-forum-arf/, diakses 17 Juni 2016 Pukul 20.58 WIB.

Alavi, Rokiah, dan Aisha Ramadan, "Narrowing development gaps in ASEAN," Journal of Economic Cooperation, Volume 29, Nomor 1, 2008.

Ba, Alice D. "Staking claims and making waves in the South China Sea: how troubled are the waters?," Contemporary Southeast Asia, A Journal of International and Strategic Affairs, Volume 33, Number 3, 2011.

Buszynski, Leszek dan Iskandar Sazlan, "Maritime claims and energy cooperation in the South China Sea", Contemporary Southeast Asia: A Journal of International and Strategic Affairs, Volume 29, Number 1, 2007.

Chheang, Vannarith, "Tourism and Regional Integration in Southeast Asia", http://ide.go.jp/English/Publish/Download/Vrf/pdf/481.pdf/.

Dutton, Peter, "Three disputes and three objectives: China and the South China Sea," Naval War College Review, Volume 64, Number 4, 2011.

Fravel, M. Taylor, "China's strategy in the South China Sea." Contemporary Southeast Asia: A Journal of International and Strategic Affairs, Volume 33, Number 3, 2011.

Gray, Julia "Life, Death, or Zombies? The Endurance of Inefficient Regional Economic Organizations", disampaikan pada Political Economy of International Organizations Conference, Princeton University, 2012 , h tt p : / / p ri n c e t n. ed u / politics/about / file repository/public/Gray_zombies_princeton_oct2012.pdf/, diakses 23 April 2016 Pukul 13.00 WIB.

Leszek Buszynski, "Rising Tensions in the South China Sea: Prospects for a Resolution of the Issue", Security Challenges, Volume 6, Number 2, 2010.

The Japan Times News, "Japan to supply Philippines with military equipment" http://japantimes.co.jp/news/2016/02/28/national/japan-to-supplyphilippines-with-military-equipment/\#.V2yAmjYkpOw/, 28 Februari 2016.

Yoshimatsu, Hidetaka, "Collective Action Problems and Regional Integration in ASEAN", Contemporary Southeast Asia: A Journal of International and Strategic Affairs, Volume 28, Nomor 1, April 2006.

HIS, International Monetary Fund, World Economic Outlook dalam McKinsey\& Company, "Understanding Asean: Seven Things You Need to Know", htt p: / / ww w. mckinsey.com/industries/public-sector/ourinsights/understanding-asean-seven-things-you-need-to-know diakses 13 Juni 2016 Pukul 14.30 WIB. 
42 PJIH Volume 3 Nomor 1 Tahun 2016 [ISSN 2460-1543] [e-ISSN 2442-9325]

\section{Dokumen Hukum}

Cebu Declaration on The Acceleration of The Establishment of an Asean

Community by 2015, 13 Januari 2007.

Charter of The Association of Southeast Asian Nation 2007.

Declaration of ASEAN Concord II (Bali Concord II) 7 Oktober 2003.

Putusan Permanent Court of Arbitration, Filipina vs Republik Rakyat Tiongkok:

PCA Case No. 2013-19, 29 Oktober 2015.

United Nations Convention on The Law of The Sea 1982. 